\title{
The effect of leadership and work discipline on teacher performance
}

\author{
Melia Wulandari ${ }^{1}$, Happy Fitria ${ }^{2}$, Achmad Wahidy ${ }^{2}$ \\ ${ }^{1}$ Sekolah Dasar Negeri 12 Rambutan, Indonesia \\ ${ }^{2}$ Universitas PGRI Palembang, Indonesia
}

\begin{tabular}{l} 
Article Info \\
\hline Article history: \\
Received Jul $15^{\text {th }}, 2021$ \\
Revised Aug $9^{\text {th }}, 2021$ \\
Accepted Aug $30^{\text {th }}, 2021$ \\
\hline
\end{tabular}

\section{Keyword:}

Leadership

Work discipline

Teacher performance

\begin{abstract}
This study aims to determine the effect of leadership and work discipline on the performance of public elementary school teachers in Cluster I, Rambutan District, Banyuasin Regency. This type of research is quantitative. The sample in the study was 55 respondents with data collection techniques in the form of a questionnaire (questionnaire). The results showed that: 1) there is a significant influence of leadership on teacher performance, 2) there is a significant effect of work discipline on teacher performance, 3) there is a significant influence between leadership and work discipline on teacher performance.
\end{abstract}

(C) 2021 The Authors. Published by IICET.

This is an open access article under the CC BY-NC-SA license

(https://creativecommons.org/licenses/by-nc-sa/4.0

\section{Corresponding Author:}

Wulandari, M.,

Sekolah Dasar Negeri 12 Rambutan, Indonesia

Email: wmelia950@gmail.com

\section{Introduction}

In ensuring the sustainability of the life of a country, education has an important role. Education is one of the ways in which intelligent, moral and autonomous individuals are created. Education is a process of building character, systemic thought, and a nation's growth so that it can contribute to the creation of the nation and state. In accordance with the trends and demands of the times, education is an absolute necessity that must continue to be established. Education must be correctly, orderly, guided and continually processed so that educational objectives can be accomplished as planned.

The introduction of education in Indonesia takes place in the educational establishment. In order to achieve the aims of education itself, one of the educational institutions is a school, which must be able to make the best and optimal contribution as a platform for the implementation of the educational process. As an educational institution, the school is an entity that, as described in the school's vision and mission, has certain objectives, including the aim of creating autonomous, personal, skilled, and accomplished students so that they can become quality human resources (HR) that can succeed in the real world.

The teacher is the determinant of the standard of quality of education, so that teachers are highly responsible for fulfilling their duties. According to [1], a teacher is an occupation or role that needs specific expertise in the performance of its primary tasks, such as teaching, guiding, directing, training, presenting examples, assessing and evaluating students at all levels of education in children's education. 
Therefore, the performance of teachers must always be enhanced, because future education is in step with the times, requiring quality and qualified technical teaching skills. So the performance of trained teachers can be a determinant of the potential success of the world of education. [2] stressed that teacher success is a manifestation of skills and abilities in their key functions and tasks, namely teaching skills, based on their authority (planning learning, carrying out learning activities, and assessing learning outcomes).

There are several variables in schools to enhance teacher performance, including management / leadership, environment, motivation, discipline of work, etc. One of the major aspects in organizational life that plays a key role is leadership. That in the cooperation process between leaders and individuals, and leaders with their communities, the leadership of a leader serves as a regulator. Leadership is an activity that influences other individuals or subordinates to want to work together to achieve those objectives, according to [3]. A leader (principalleadership )'s would be able to distinguish between an entity and another. The style of leadership held by the leader (principal) in leading an organization will impact the teacher's performance. In line with research conducted by [4], based on the results of the study, it was found that there was a positive and significant effect of school principal leadership on teacher performance.

What is no less important, apart from leadership, is job discipline. For organizational growth, discipline is very important, it is mainly used to encourage workers to be able to discipline themselves both individually and in groups in carrying out work. Discipline is a feeling that he is obedient and obedient to the ideals that his duty is assumed to be. Discipline is both an individual and a community that ensures compliance with orders and takes the initiative to take the appropriate steps in the absence of orders [5]. Another concept of job discipline continued, namely procedures that correct or punish violation of rules or procedures [6]. Discipline represents a state or attitude of reverence that occurs in workers for the laws and regulations that exists within an organization. In accordance with research from [7], the discipline of teacher work has a major influence on teacher success at Prabumulih Public High School.

Performance is a real action, according to [8], that is shown by everyone as a job accomplishment. The performance of teachers will decrease if leadership and work discipline do not go well. Some teachers who teach in class are still relying on their past experience from time to time because of the lack of managerial principal from the observations made, one of which is from the way of teaching, so they feel they have mastered the material outside their head and do not want to adapt to new things, like learning strategies, using media, a poorly understood scoring system and teaching by rote or without training for previous teaching. The lack of oversight from the principal (supervision) that should be done twice a semester is one of the reasons.

Similar to the ongoing job discipline, some teachers arrive later than the scheduled time and leave early, based on findings and teacher attendance. Every Monday at $07.00 \mathrm{WIB}$, all teachers are also expected to conduct the Flag Ceremony, but in fact only some teachers arrive on time and some even come after the completion of the Flag Ceremony. In addition to less firm penalties for those who break school laws, firm penalties will make law violators understand their errors and not repeat them again, whether in the form of reprimands and written warnings. This is due to the lack of successful regulation by leaders/principals of schools.

Thus, in the above case, the efficiency of the teacher can be affected by the principal's leadership and the teacher's own job discipline in carrying out his duties. Therefore, as the leader of an organisation, the principal should be able to see the deficiencies required by his subordinates in order to increase the achievement and performance of teachers, including by motivating teachers to conduct their duties according to the rules and directions. Since success is closely linked to the school organization's leadership and even the teachers' own interests. For teachers, a performance assessment may serve as input on different aspects, such as skills, abilities, weaknesses, and potential. It can also be useful in deciding priorities, directions, plans and growth for the career of a teacher. But it's really important to do periodic teacher performance reviews. It would definitely be an image of the success or failure of a teacher in carrying out his duties as an educator with an evaluation of teacher efficiency.

\section{Method}

The method used in this research is quantitative research methods. According to [9] quantitative research is research that is focused on the study of objective phenomena to be studied quantitatively. Data collection using a questionnaire or questionnaire. According to [10] Questionnaire / questionnaire is a data collection method which is done by giving a set of questions / written statements to respondents to respond according to user requests. 
The data scale used is the Likert scale, the Likert scale is a research scale used to measure attitudes and opinions. This scale assesses the attitudes or behavior desired by researchers by asking several questions to respondents. Then the respondent is asked to provide a choice of answers or responses on the measurement scale that has been provided [11].

Data analysis used descriptive data analysis, t-test analysis, F-test analysis, and statistical coefficient of determination in order to test the predetermined hypothesis. The data was collected quantitatively, while the method in this study used the partial correlation method. Partial correlation is used for hypothesis testing analysis if the researcher intends to determine the effect of the independent and dependent variables, where one of the independent variables is controlled (made fixed) [12]. The calculation uses the data processing application SPSS program version 24.0.

This study used a sample of 55 public elementary school teachers in Cluster 1, Rambutan District, Banyuasin Regency. The quantitative research variables tested in this study consisted of leadership (X1) on teacher performance (Y), work discipline (X2) on teacher performance (Y), leadership (X1) and work discipline $(\mathrm{X} 2)$ on teacher performance $(\mathrm{Y})$, then all the data obtained will be processed and processed with quantitative analysis.

\section{Results and Discussions}

Hypothesis testing was continued after testing the data analysis requirements, namely the normality test, linearity test and multicollinearity test. After the data is declared to have met the requirements to be tested, then the hypothesis is tested using the t test and the $\mathrm{F}$ test, to determine the effect partially and simultaneously on the variables to be tested.

\section{First Hypothesis Testing (H1)}

Table $1<$ Results of Variable t-test analysis (X1) to $\mathrm{Y}>$

\begin{tabular}{|c|c|c|c|c|c|c|}
\hline \multicolumn{7}{|c|}{ Coefficients $^{\mathrm{a}}$} \\
\hline \multirow[b]{2}{*}{ Model } & & \multicolumn{2}{|c|}{ Unstandardized Coefficients } & $\begin{array}{l}\text { Standardized } \\
\text { Coefficients }\end{array}$ & \multirow[b]{2}{*}{ t } & \multirow[b]{2}{*}{ Sig. } \\
\hline & & B & Sta. Error & Beta & & \\
\hline \multirow[t]{2}{*}{1} & (Constant) & 25.292 & 9.975 & & 2.536 & .014 \\
\hline & Disiplin Kerja & .696 & .147 & .546 & 4.749 & .000 \\
\hline
\end{tabular}

(Source: SPSS Application Program Analysis version 24)

Based on the simple linear regression test above, the $t$ value is 3,880 . Then the table value is sought in the t statistical table with $\alpha=0.05$ and degrees of freedom $(\mathrm{df}) \mathrm{n}-2$ or $55-2=53$ ( $\mathrm{n}$ is the amount of data), the $\mathrm{t}$ table results are 2.005. So the value of $t$ count (3.880)> t table (2.005), so that Hol is rejected and Ha1 is accepted. Then for the significance test calculated by the SPSS application program version 24 obtained a significant value of $0.000<0.05$, so that Hol is rejected and Hal is accepted, which means that there is a significant influence between $\mathrm{X} 1$ and $\mathrm{Y}$.

\section{Second Hypothesis Testing (H2)}

Table $2<$ Results of Variable t-test analysis (X2) to Y>

\begin{tabular}{|c|c|c|c|c|c|c|}
\hline \multicolumn{7}{|c|}{ Coefficients $^{a}$} \\
\hline & & \multicolumn{2}{|c|}{ Unstandardized Coefficients } & \multirow{2}{*}{$\begin{array}{c}\text { Standardized } \\
\text { Coefficients } \\
\text { Beta }\end{array}$} & \multirow[b]{2}{*}{$t$} & \multirow[b]{2}{*}{ Sig. } \\
\hline Model & & $B$ & Std. Error & & & \\
\hline \multirow[t]{2}{*}{1} & (Constant) & 25.292 & 9.975 & & 2.536 & .014 \\
\hline & Disiplin Kerja & .696 & .147 & .546 & 4.749 & .000 \\
\hline
\end{tabular}

(Source: SPSS Application Program Analysis version2

Based on the simple linear regression test above, the t-value is 4.749 . Then the t table value is sought in the $t$ statistical table with $\alpha=0.05$ and degrees of freedom (df) $n-2$ or $55-2=53$ ( $n$ is the amount of data), the $t$ table results are 2.005. So the value of $t$ count (4.749)> $t$ table (2.005), so that Hol is rejected and Hal is 
accepted. Then for the significance test calculated by the SPSS application program version 24 obtained a significant value of $0.000<0.05$, so that Hol is rejected and Hal is accepted, which means that there is a significant influence between $\mathrm{X} 2$ and $\mathrm{Y}$.

\section{Third Hypothesis Testing (H3)}

Table $3<$ Results of the F Test Analysis $>$

\begin{tabular}{|c|c|c|c|c|c|c|}
\hline \multicolumn{7}{|c|}{ ANOVA $^{\mathrm{a}}$} \\
\hline \multicolumn{2}{|l|}{ Model } & $\begin{array}{l}\text { Sum of } \\
\text { Squares }\end{array}$ & df & Mean Square & $\mathrm{F}$ & Sig. \\
\hline \multirow[t]{3}{*}{1} & Regression & 1707.638 & 2 & 853.819 & 16.987 & $.000^{\mathrm{b}}$ \\
\hline & Residual & 2613.744 & 52 & 50.264 & & \\
\hline & Total & 4321.382 & 54 & & & \\
\hline
\end{tabular}

(Source: SPSS Application Program Analysis version

From the Anova test above, it is obtained that $\mathrm{F}$ count is 16,987 . Then the $\mathrm{F}$ table value is sought in Table F Statistics with a significance level of $\alpha=0.05$, df1 (number of variables $-1=2$ ), df2 at nk-1 $(55-2-1=52$ ), obtained $\mathrm{F}$ table of 3.18 . By comparing the calculated $\mathrm{F}$ value and $\mathrm{F}$ table, it is known that the calculated $\mathrm{F}$ value $(16,987)>\mathrm{F}$ table (3.18), so that $\mathrm{Ho} 3$ is rejected and $\mathrm{Ha} 3$ is accepted. Then for the significance test the Sig value is obtained. amounting to 0,000 . This value is less than 0.05 , so that Ho3 is rejected and Ha3 is accepted, which means that there is a significant influence X1 and X2 simultaneously on $\mathrm{Y}$.

Based on the results of the analysis of research data in CHAPTER IV using the SPSS program version 24. Before the research was carried out, the data requirements were tested first, namely the validity test and the reliability test. The data validity test was conducted by using the validation test which was carried out with the validator, namely PGRI Palembang University lecturers. Then proceed to the analysis validity test using the calculation of the SPSS program version 24. The results of the analysis validation calculation for the leadership variable note that there are four invalid items so that the four statements are discarded and only use 17 (seventeen) statement items for further testing. The results of the calculation of the validation analysis for the work discipline variable note that there are five invalid items so that the five statements are discarded and only use 15 (fifteen) statement items for further testing. The results of the calculation of the validation analysis for the teacher performance variable note that there are three invalid items so that the three statements are discarded and only use 17 (seventeen) statement items for further testing. Then the data prerequisite test was continued to the reliability test. After calculating using the SPSS version 24 program, it is known that the variables of leadership, work discipline, and teacher performance each get a value of $r$ greater than $r$ table so that it can be concluded that all research variables are declared reliable.

\section{Conclusions}

Based on the results of the research that has been done, it can be concluded that there is a significant influence of leadership on the performance of SD Negeri teachers in Cluster I, Rambutan District, Banyuasin Regency, which has answered the first hypothesis. There is a significant effect of work discipline on the performance of public elementary school teachers in Cluster I, Rambutan District, Banyuasin Regency, which has answered the second hypothesis. There is a significant influence of leadership and work discipline together on the performance of public elementary school teachers in Cluster I, Rambutan District, Banyuasin Regency, which has answered the third hypothesis.

\section{References}

Edison, Emron dkk. (2016). Manajemen Sumber Daya Manusia. Bandung: Alfabeta.

Firsda, E., Arafat, Y. \& Wahidy, A. (2020). Pengaruh Tunjangan Profesi dan Disiplin Kerja Guru terhadap Kinerja Guru. Da'wah and Communication Isamic Journal, Vol.1 No.3.

Fitria, Happy dkk. (2020). Pengaruh Kepemimpinan Kepala Sekolah dan Disiplin Kerja Guru terhadap Kinerja Guru SDN di Kecamatan Sembawa. Jurnal Pendidikan Tambusai. 4(3):1883-1894.

Heidjrachman dan Suad, Husnan. (2002). Manajemen Personalia. Yogyakarta: Badan Penerbit Fakultas Ekonomi (BPFE).

Imran. (2010). Pembinaan Guru Di Indonesia. Jakarta: Pustaka Jaya. 
Kristiawan, dkk. (2017). Inovasi Pendidikan. Jawa Timur: Wade Group.

Musfiqon. (2012). Pengembangan media dan Sumber Media Pembelajaran. Jakarta: Prestasi Pustakaraya.

Rivai, Veithzal. (2011). Manajemen Sumber Daya Manusia untuk Perusahaan, dari Teori ke Praktik. Jakarta: Raja Grafindo Persada.

Simamora, Henry. (2015). Manajemen Sumber Daya Manusia. Yogyakarta: STIEY.

Sugiyono. (2016). Metode Penelitian Kuantitatif, Kualitatif, dan R\&D. Bandung: Alfabeta.

Sukardi. (2011). Metodologi Penelitian Pendidikan. Jakarta: Bumi Aksara.

Widoyoko, Eko Putro. (2017). Teknik Penyusunan Instrumen Penelitian. Yogyakarta: Pustaka Pelajar. 